\title{
Front Matter: Volume 8296
}

, "Front Matter: Volume 8296," Proc. SPIE 8296, Computational Imaging X, 829601 (22 February 2012); doi: 10.1117/12.927877 SPIE. Event: IS\&T/SPIE Electronic Imaging, 2012, Burlingame, California, United 


\section{PROCEEDINGS \\ IS\&T/SPIE \\ Electronic \\ Imaging \\ Science and Technology}

\section{Computational Imaging $X$}

Charles A. Bouman

llya Pollak

Patrick J. Wolfe

Editors

23-24 January 2012

Burlingame, California, United States

Sponsored and Published by

IS\&T-The Society for Imaging Science and Technology

SPIE 
The papers included in this volume were part of the technical conference cited on the cover and title page. Papers were selected and subject to review by the editors and conference program committee. Some conference presentations may not be available for publication. The papers published in these proceedings reflect the work and thoughts of the authors and are published herein as submitted. The publishers are not responsible for the validity of the information or for any outcomes resulting from reliance thereon.

Please use the following format to cite material from this book:

Author(s), "Title of Paper," in Computational Imaging $X$, edited by Charles A. Bouman, Ilya Pollak, Patrick J. Wolfe, Proceedings of SPIE-IS\&T Electronic Imaging, SPIE Vol. 8296, Article CID Number (2012).

ISSN 0277-786X

ISBN 9780819489432

Copublished by

\section{SPIE}

P.O. Box 10, Bellingham, Washington 98227-0010 USA

Telephone +1 3606763290 (Pacific Time) · Fax +1 3606471445

SPIE.org

and

IS\&T-The Society for Imaging Science and Technology

7003 Kilworth Lane, Springfield, Virginia, 22151 USA

Telephone +1 7036429090 (Eastern Time) · Fax +1 7036429094

imaging.org

Copyright (C) 2012, Society of Photo-Optical Instrumentation Engineers and The Society for Imaging Science and Technology.

Copying of material in this book for internal or personal use, or for the internal or personal use of specific clients, beyond the fair use provisions granted by the U.S. Copyright Law is authorized by the publishers subject to payment of copying fees. The Transactional Reporting Service base fee for this volume is $\$ 18.00$ per article (or portion thereof), which should be paid directly to the Copyright Clearance Center (CCC), 222 Rosewood Drive, Danvers, MA 01923. Payment may also be made electronically through CCC Online at copyright.com. Other copying for republication, resale, advertising or promotion, or any form of systematic or multiple reproduction of any material in this book is prohibited except with permission in writing from the publisher. The CCC fee code is $0277-786 \mathrm{X} / 12 / \$ 18.00$.

Printed in the United States of America.

Paper Numbering: Proceedings of SPIE follow an e-First publication model, with papers published first online and then in print and on CD-ROM. Papers are published as they are submitted and meet publication criteria. A unique, consistent, permanent citation identifier (CID) number is assigned to each article at the time of the first publication. Utilization of CIDs allows articles to be fully citable as soon as they are published online, and connects the same identifier to all online, print, and electronic versions of the publication. SPIE uses a six-digit CID article numbering system in which:

- The first four digits correspond to the SPIE volume number.

- The last two digits indicate publication order within the volume using a Base 36 numbering system employing both numerals and letters. These two-number sets start with 00, 01, 02, 03, 04, 05 , 06, 07, 08, 09, OA, OB ... 0Z, followed by 10-1Z, 20-2Z, etc.

The CID number appears on each page of the manuscript. The complete citation is used on the first page, and an abbreviated version on subsequent pages. Numbers in the index correspond to the last two digits of the six-digit CID number. 


\title{
Contents
}

\author{
vii Conference Committee \\ ix Keynote Presentation Slide Information
}

\section{SESSION 1 SPECIAL SESSION ON MICROPSCOPY AND INFORMATION MODELING}

829606 Image sequence segmentation combining global labeling and local relabeling and its application to materials science images [8296-04]

J. W. Waggoner, Univ. of South Carolina (United States); J. Simmons, Air Force Research Lab.

(United States); S. Wang, Univ. of South Carolina (United States)

829608 Computer-aided fiber analysis for crime scene forensics [8296-06]

M. Hildebrandt, Otto-von-Guericke-Univ. of Magdeburg (Germany); C. Arndt, Brandenburg

Univ. of Applied Sciences (Germany); A. Makrushin, Otto-von-Guericke-Univ. of Magdeburg (Germany) and Brandenburg Univ. of Applied Sciences (Germany); J. Dittmann,

Otto-von-Guericke-Univ. of Magdeburg (Germany)

8296 OA 3D reconstruction based on single-particle cryo electron microscopy images as a random signal in noise problem [8296-08]

Q. Wang, Cornell Univ. (United States); Y. Zheng, Lawrence Berkeley National Lab. (United

States); P. C. Doerschuk, Cornell Univ. (United States)

8296 OB Highly scalable methods for exploiting a label with unknown location in order to orient a set of single-particle cryo electron microscopy images [8296-09]

C. J. Prust, Milwaukee School of Engineering (United States); Q. Wang, P. C. Doerschuk,

Cornell Univ. (United States); J. E. Johnson, The Scripps Research Institute (United States)

\section{SESSION 2 RECONSTRUCTION}

8296 OD Image reconstruction using projections from a few views by discrete steering combined with DART [8296-11]

J. Kwon, S. M. Song, B. Kauke, D. P. Boyd, TeleSecurity Sciences, Inc. (United States)

$8296 \mathrm{OE}$ One-dimensional control grid interpolation-based demosaicing and color image interpolation [8296-12]

C. M. Zwart, D. H. Frakes, Arizona State Univ. (United States)

8296 OF Limited view angle iterative $\mathrm{CT}$ reconstruction [8296-13]

S. J. Kisner, E. Haneda, C. A. Bouman, Purdue Univ. (United States); S. Skatter, M. Kourinny, Morpho Detection, Inc. (United States); S. Bedford, Astrophysics, Inc. (United States)

8296 OG Variational semi-blind sparse image reconstruction with application to MRFM [8296-15]

S. U. Park, Univ. of Michigan (United States); N. Dobigeon, Univ. of Toulouse (France);

A. O. Hero, Univ. of Michigan (United States) 
$8296 \mathrm{OH}$ Moon search algorithms for NASA's Dawn Mission to asteroid Vesta [8296-16]

N. Memarsadeghi, L. A. McFadden, D. R. Skillman, NASA Goddard Space Flight Ctr. (United States); B. McLean, M. Mutchler, Space Telescope Science Institute (United States);

U. Carsenty, DLR, Institute of the Planetary Research (Germany); E. E. Palmer, Planetary Science Institute (United States)

8296 OK Multichannel hierarchical image classification using multivariate copulas [8296-19]

A. Voisin, V. A. Krylov, INRIA Sophia Antipolis Méditerranée (France); G. Moser, S. B. Serpico, Univ. of Genoa (Italy); J. Zerubia, INRIA Sophia Antipolis Méditerranée (France)

\section{SESSION 4 ENHANCEMENT, DENOISING, AND RESTORATION I}

8296 OM Denoising and deblurring of Fourier transform infrared spectroscopic imaging data [8296-20]

T. H. Nguyen, R. K. Reddy, M. J. Walsh, M. Schulmerich, G. Popescu, M. N. Do, R. Bhargava, Univ. of Illinois at Urbana-Champaign (United States)

$82960 \mathrm{~N}$ Iterative weighted risk estimation for nonlinear image restoration with analysis priors [8296-21]

S. Ramani, J. Rosen, Z. Liu, J. A. Fessler, Univ. of Michigan (United States)

$829600 \quad$ Nonlocal transform-domain denoising of volumetric data with groupwise adaptive variance estimation [8296-22]

M. Maggioni, A. Foi, Tampere Univ. of Technology (Finland)

8296 OP Non-uniform contrast and noise correction for coded source neutron imaging [8296-23] H. J. Santos-Villalobos, P. R. Bingham, Oak Ridge National Lab. (United States)

$82960 Q \quad$ Image enhancement and quality measures for dietary assessment using mobile devices [8296-24]

C. Xu, F. Zhu, N. Khanna, Purdue Univ. (United States); C. J. Boushey, Purdue Univ. (United States) and Univ. of Hawaii Cancer Ctr. (United States); E. J. Delp, Purdue Univ. (United States)

\section{SESSION 5 ENHANCEMENT, DENOISING, AND RESTORATION II}

8296 OS Subjective evaluations of example-based, total variation, and joint regularization for image processing [8296-26]

H. S. Anderson, Sandia National Labs. (United States); M. R. Gupta, Univ. of Washington (United States); J. Hardeberg, Gjøvik Univ. (Norway)

8296 OT Removal of haze and noise from a single image [8296-27]

E. Matlin, P. Milanfar, Univ. of California, Santa Cruz (United States) 
$82960 \mathrm{U} \quad$ Finding saliency in noisy images [8296-28]

C. Kim, P. Milanfar, Univ. of California, Santa Cruz (United States)

8296 OV Automatic loop closure detection using multiple cameras for 3D indoor localization [8296-29]

J. Kua, N. Corso, A. Zakhor, Univ. of California, Berkeley (United States)

8296 OW An information theoretic trackability measure [8296-30]

S. T. Acton, A. Aksel, Univ. of Virginia (United States)

8296 0X Text replacement on cylindrical surfaces: a semi-automatic approach [8296-31] H. Ding, R. Bala, Z. Fan, Xerox Corp. (United States); C. A. Bouman, J. P. Allebach, Purdue Univ. (United States)

$82960 Z$ Registration and integration of multiple depth images using signed distance function [8296-42]

D. B. Kubacki, H. Q. Bui, S. D. Babacan, M. N. Do, Univ. of Illinois at Urbana-Champaign (United States)

829610 Image reconstruction from nonuniformly spaced samples in Fourier domain optical coherence tomography [8296-14]

J. Ke, R. Zhu, E. Y. Lam, The Univ. of Hong Kong (Hong Kong, China)

INTERACTIVE PAPER SESSION

829611 Analysis of the practical coverage of uniform motions to approximate real camera shakes [8296-33]

H. Cho, S. Cho, POSTECH (Korea, Republic of); Y. S. Moon, J. Cho, S. Lee, Samsung

Electronics Co., Ltd. (Korea, Republic of); S. Lee, POSTECH (Korea, Republic of)

829612 Real-time computational camera system for high-sensitivity imaging by using combined long/short exposure [8296-34]

S. Sato, Y. Okada, T. Azuma, Panasonic Corp. (Japan)

829613 Color correction with edge preserving and minimal SNR decrease using multi-layer decomposition [8296-35]

B. K. Park, W. Choe, J. Lim, S. Lee, C. Kim, Samsung Electronics Co., Ltd. (Korea, Republic of)

829614 Bayesian image superresolution for hyperspectral image reconstruction [8296-36]

Y. Murayama, A. Ide-Ektessabi, Kyoto Univ. (Japan)

829615 ToF depth image motion blur detection using 3D blur shape models [8296-37]

S. Lee, H. Shim, J. D. K. Kim, C. Y. Kim, Samsung Advanced Institute of Technology (Korea, Republic of)

829616 Computational imaging of defects in commercial substrates for electronic and photonic devices [8296-38]

M. Fukuzawa, R. Kashiwagi, M. Yamada, Kyoto Institute of Technology (Japan) 
829617 Nondestructive three-dimensional measurement of gas temperature distribution by phase tomography [8296-39]

S. Tomioka, S. Nishiyama, Hokkaido Univ. (Japan)

829618 Closed-form inverses for the mixed pixel/multipath interference problem in AMCW lidar [8296-40]

J. P. Godbaz, M. J. Cree, A. A. Dorrington, Univ. of Waikato (New Zealand)

Author Index 


\title{
Conference Committee
}

\author{
Symposium Chairs \\ Majid Rabbani, Eastman Kodak Company (United States) \\ Gaurav Sharma, University of Rochester (United States)
}

Conference Chairs

Charles A. Bouman, Purdue University (United States)

Ilya Pollak, Purdue University (United States)

Patrick J. Wolfe, Harvard University (United States)

Program Committee

Samit Basu, GE Security (United States)

Thomas S. Denney, Jr., Auburn University (United States)

Maya R. Gupta, University of Washington (United States)

Eric L. Miller, Tufts University (United States)

Joseph A. O'Sullivan, Washington University in St. Louis (United States)

Zygmunt Pizlo, Purdue University (United States)

Stanley J. Reeves, Auburn University (United States)

Yongyi Yang, Illinois Institute of Technology (United States)

\section{Session Chairs}

Keynote Presentation

Charles A. Bouman, Purdue University (United States)

1 Special Session on Micropscopy and Information Modeling

Charles A. Bouman, Purdue University (United States)

2 Reconstruction

Charles A. Bouman, Purdue University (United States)

3 Classification and Detection

Charles A. Bouman, Purdue University (United States)

4 Enhancement, Denoising, and Restoration I

Charles A. Bouman, Purdue University (United States)

5 Enhancement, Denoising, and Restoration II

Charles A. Bouman, Purdue University (United States) 
6 Computer Vision and 3D Modeling

Charles A. Bouman, Purdue University (United States)

viii

Downloaded From: https://www.spiedigitallibrary.org/conference-proceedings-of-spie on 26 Apr 2023 Terms of Use: https://www.spiedigitallibrary.org/terms-of-use 
SPIE Computational Imaging $X, 8296-1$ January $23^{\text {rd }}, 2012$

\title{
Imaging with Electrons: A Review of Modern Modalities
}

\author{
Marc De Graef
}

Department of Materials Science \& Engineering

Carnegie Mellon University

Pittsburgh, PA

Partial Support: DOE DE-FG02-0IER45893

The slides from Marc De Graef's keynote presentation, Imaging with Electrons: A Review of Modern Modalities, are available at http://materials.cmu.edu/degraef/ClC2012-keynote.pdf. 
Downloaded From: https://www.spiedigitallibrary.org/conference-proceedings-of-spie on 26 Apr 2023

Terms of Use: https://www.spiedigitallibrary.org/terms-of-use 